\title{
Bestemmelse av termin og fosteralder - teknologi, biologi eller begge deler?
}

En nasjonal standard for bestemmelse av termin og fosteralder må inkludere både teknologisk og biologisk
informasjon. Ultralydundersøkelse og vurdering med enten Terminhjulet eller eSnurra vil derfor sammen
med en god klinisk vurdering av menstruasjonsanamnesen sikre en bedre terminfastsettelse for gravide enn det den enkelte metode brukt alene vil gi.

Som barnelege og neonatolog har jeg gjennom flere år med interesse fulgt debatten omkring terminbestemmelse ved hjelp av tidlig ultralyd og den faglige uenigheten mellom miljøene bak henholdsvis Terminhjulet og eSnurra. Det som særlig har interessert meg, er den sterke troen på at tidlig ultralydundersøkelse er den eneste brukbare metoden, og at striden mellom fagmiljøene derfor først og fremst står om hvilken ultralydmetode som er den beste (1-6).

\section{Ultralydtermin er alltid gal}

Det er svært overraskende at ingen i de to fagmiljøene trekker frem den enkelte kvinnens menstruasjonsanamnese som en relevant og viktig klinisk informasjon for denne problemstillingen. Selv om Naegeles regel av ulike grunner kan være både usikker og gal, vil kvaliteten på ultralydundersøkelsen også kunne variere med undersøkerens kompetanse og med hvilket ultralydutstyr som brukes (7).

Dessuten er en ultralydbasert termin alltid gal, fordi den baserer seg på en umulig forutsetning om at alle fostre er like store ved tidspunktet for ultralydundersøkelsen (2). Dette medfører at de kvinnene som har et foster som er større eller mindre enn gjennomsnittet, vil få en feilaktig forlengelse eller forkortelse av fosteralderen. Når fosteret er litt mindre enn gjennomsnittet, vil ultralydundersøkelsen tolke det som om svangerskapet har kommet kortere enn det egentlig har, og terminen forskyves utover i tid. På samme måte vil fostre som er større enn gjennomsnittet, bli vurdert som å ha kommet lenger i svangerskapet, og terminen vil fastsettes tidligere. Denne feilkilden er utvilsomt av størst betydning der ultralydundersøkelsen fører til en forlengelse av svangerskapet med risiko for uheldig overtid dersom fødselen ikke starter spontant. Metodefeilen kan også ha betydning for vurdering av behandlingsstrategi ved mulig prematur fødsel.

\section{Byråkratiske hensyn fremfor medisinske}

På denne bakgrunn har det overrasket meg at Helsedirektoratet nylig har engasjert seg i denne problemstillingen ved å anbefale at eSnurra bør innføres som nasjonalt verktøy (standard) for bestemmelse av termin og fosteralder (8). Direktoratet begrunner sin anbefaling med at man ved bruk av bare ett nasjonalt verktøy sikrer abortsøkende kvinner likhet for loven, gir lik vurdering ved preterme fødsler og entydig vurdering av overtidighet. Dette høres ut som en akseptabel byråkratisk målsetting. Det er imidlertid langt fra sikkert at dette gir det medisinsk mest riktige resultat for alle svangerskap - og det må vel være det viktigste.

Etter min erfaring er det ikke uvanlig at ultralydundersøkelsen medfører at den kliniske terminen fastlegen har satt på helsekortet på grunnlag av menstruasjonsopplysningene fra kvinnen, forskyves utover med én uke eller to. Mange barneleger har opplevd at denne teknologiske forlengelsen av svangerskapet kan få dramatiske konsekvenser for utfallet ved at den kan medføre alvorlig overtid, om ikke fødselen kommer spontant i gang. På den annen side vil en ultralydtermin som er tidligere enn den terminen som er fastsatt klinisk, i noen tilfeller kunne medføre teknologisk overtidighet før svangerskapet er fullgått.

Det har dessverre forekommet at kvinner med en biologisk termin som er ansett som sikker, likevel har følt seg presset til å godta at fødselen blir indusert før klinisk termin, ut fra henvisning til at hun påtar seg et betydelig ansvar dersom hun lar svangerskapet gå lenger enn avdelingens ultralydbaserte retningslinjer fastslår. Et slikt press vil antagelig bli økende dersom det ikke bare henvises til én enkelt avdelings retningslinjer, men en nasjonal standard fra Helsedirektoratet.

\section{Menstruasjonsanamnesen må inkluderes}

På denne bakgrunn bør fagmiljøene og Helsedirektoratet kommunisere hvor viktig det er at alle kvinner i fertil alder er bevisste på sin menstruasjonsanamnese. Det er ingen grunn til å tro at en kvinne med en god menstruasjonsanamnese og sikker klinisk termin, vil få en riktigere eller bedre terminfastsettelse med en metode basert på ultralyd alene. I den forbindelse har det heller ikke vært kommentert at det er store forskjeller mellom avdelingene med hensyn til hvordan de forholder seg til forskjeller mellom klinisk og teknologisk termin. Noen avdelinger ser konsekvent helt bort fra terminen fastlegen har satt på helsekortet, og den er ofte heller ikke journalført i ultralydjournalen. Andre avdelinger vektlegger i ulik grad også biologisk termin når endelig termin fastsettes. Dette bør selvfølgelig standardiseres.
Ultralydundersøkelse og vurdering med enten Terminhjulet eller eSnurra vil sammen med en god klinisk vurdering av menstruasjonsanamnesen sikre en bedre terminfastsettelse for gravide enn det den enkelte metode brukt alene vil gi.

\section{Dag Bratlid}

bratlid@vikenfiber.no

Dag Bratlid (f. 1944) er tidligere professor ved Norges teknisk-naturvitenskapelige universitet. Han er spesialist i pediatri og tidligere overlege i nyfødtmedisin ved Barne- og ungdomsklinikken, St. Olavs hospital, og har vært leder av interessegruppen for nyfødtmedisin i Barnelegeforeningen. Bratlid er nå tilknyttet Avdeling for helseledelse og helseøkonomi ved Universitetet i Oslo.

Forfatteren har fylt ut ICMJE-skjemaet og oppgir ingen interessekonflikter.

\section{Litteratur \\ Eik-Nes S, Grøttum P. Graviditetskalenderen Snurra. Drammen: Scan-Med A/S, 1983. \\ 2. Bratlid D. Bestemmelse av fødselstermin ved tidlig ultralydundersøkelse-galt, galere, galest? Tidsskr Nor Lægeforen 1991; 111: 1379-81. \\ 3. Kiserud T, Rasmussen S. Terminbestemmelse ved hjelp av ultralyd-kan metoden bli bedre? Tidsskr Nor Lægeforen 1999; 119: 4331-4. \\ 4. Bratlid D. Terminbestemmelse ved hjelp av ultra- lyd. Tidsskr Nor Lægeforen 2000; 120: 1079 \\ 5. Gjessing HK, Grøttum P. Eik-Nes SH. A direct method for ultrasound prediction of day of delivery: a new, population-based approach. Ultrasound Obstet Gynecol 2007: 30: 19-27. \\ 6. Kiserud T, Johnsen SL, Rasmussen S. Re: A direct method for ultrasound prediction of day of delivery: a new, population-based approach. Problems of accounting for a retrospective selection. Ultra- sound Obstet Gynecol 2008; 31: 225; author reply $225-7$ \\ 7. Økland I, Bjåstad TG, Johansen TF et al. Narrowed beam width in newer ultrasound machines shor- tens measurements in the lateral measurement charts may be obsolete. Ultrasound Obstet Gynecol 2011; 38: $82-7$ \\ 8. Janbu T. Nasjonalt verktøy for bestemmelse av termin og fosteralder. Tidsskr Nor Legeforen 2016; 136: 790-1.}

Mottatt 7.8. 2016 og godkjent 9.8. 2016. Redaktør: Ketil Slagstad.

Engelsk oversettelse på www.tidsskriftet.no

Publisert først på nett. 